\title{
Estimation of Runoff and Sediment Yield Using SWAT Model: The Case of Katar Watershed, Rift Valley Lake Basin of Ethiopia
}

\author{
Dulo Husen ${ }^{1,}$, Brook Abate ${ }^{2}$ \\ ${ }^{1}$ Oromia Agricultural Research Institute, Adami Tulu Agricultural Research Center, Adami Tulu, Ethiopia \\ ${ }^{2}$ College of Architecture and Civil Engineering, Addis Ababa Science and Technology University (ASTU), Addis Ababa, Ethiopia
}

Email address:

dulohusen196@gmail.com (D. Husen),brooka12@gmail.com (B. Abate)

\section{To cite this article:}

Dulo Husen, Brook Abate. Estimation of Runoff and Sediment Yield Using SWAT Model: The Case of Katar watershed, Rift Valley Lake Basin of Ethiopia. International Journal of Mechanical Engineering and Applications. Vol. 8, No. 6, 2020, pp. 125-134.

doi: 10.11648/j.ijmea.20200806.11

Received: September 16, 2020; Accepted: September 28, 2020; Published: November 19, 2020

\begin{abstract}
Estimating runoff and sediment yield at watershed level is important for better understanding of hydrologic processes and identifying hotspot area by using Soil and Water Assessment Tool (SWAT) model for intervention strategies. From the result of Global sensitivity analysis, 12 highly sensitive parameters identified. The obtained results were satisfactory for the gauging station (coefficient of determination $\left(\mathrm{R}^{2}\right)=0.8$, Nash-Sutcliffe Efficiency (NSE) $=0.6$ and percent difference or percent bias (PBIAS) $=0$ ) from 1990 to 2005(16) years used calibration and $\left(\mathrm{R}^{2}=0.6\right.$, ENS $=0.55$ and PBIAS=1.2) from 2006 to 2013(8 year) were used for validation period respectively. Among all sub-watersheds, nine sub watersheds were more vulnerable to soil loss and potentially prone to erosion risk, which was out of range of tolerable soil loss rate $\left(18 \operatorname{tha}^{-1} \mathrm{yr}^{-1}\right)$. In conclusion, the SWAT model could be effectively used to estimate runoff and sediment yield; and identified hotspot area. In addition, the result could help different stakeholders to plan and implement appropriate interventions strategies in the Katar watershed.
\end{abstract}

Keywords: Runoff, Sediment Yield, SWAT, Calibration and Validation

\section{Introduction}

Out of 60 million hectares estimated to be agriculturally productive lands, about 27 million hectares are significantly eroded, 14 million hectares are seriously eroded and 2 million hectares have reached the point of no return [6]. Another report by the Soil Conservation Research Project [31] of Ethiopia indicated that the rate of soil loss in extreme cases ranges from 0 to $300 \mathrm{t} \mathrm{ha}^{-1} \mathrm{yr}^{-1}$ with an average loss of $70 \mathrm{t} \mathrm{ha}^{-1} \mathrm{yr}^{-1}$, which is beyond the concept of any tolerable soil loss.

Land cover change is massively and rapidly taking place, as elsewhere in the Ethiopian Central Rift Valley (CRV) [7] and CRV is one of the environmental vulnerable areas in the country. Katar watershed is under heavy pressures [17], climate change [34] and the intensification of agricultural development activities were increasing from time to time [32] as a result huge amount of soil losses from the study area, and some areas under high and sever soil erosion. Large area of Katar watershed covered by Haplic Luvisols (high clay content) and agriculture is the dominant activities in area. Hence, soil in some parts of sub watershed is highly eroded, due to fragile ecosystem and inherent erodible nature of the soils and some parts of this watershed is already taken out of cultivation due to land dissected by gully.

Most recently, watershed management is an approach followed by the government of Ethiopia in the form of mass mobilizations to protect soil from erosion in particular and to reverse land degradation in general $[8,13,25]$. However, past soil conservation efforts did not bring significant changes to the ongoing soil degradation problems $[4,24]$. Whereas, dramatic reduction has been made in arresting soil erosion [11] and the approach has not been supported with intervention prioritizing techniques that identify highly susceptible erosion prone areas. Identification of erosionprone areas using a distributed physical model that estimates 
soil erosion rates with sufficient accuracy will be important for implementing appropriate erosion control practices [30].

Therefore, it is very important to assess the runoff and sediments yield from the watershed and develop sediment loss map in the area before formulation of any soil and water conservation strategies. Estimation of runoff and sediment yield not studied in depth in the Katar watershed. The Katar watershed is one of the central highland basins in the Rift Valley region of Ethiopia; where soil erosion is rampant. Hence, to solve this, there is a need to identify the most erosion prone areas in the watershed for appropriate watershed management. The SWAT model is a suitable model, which is used for estimating runoff and sediment loss and provided information for the sustainable development of the land and water resources of the study watershed.

Therefore, the purpose of this study was to estimate runoff and sediment yield from watershed and categorizing the watershed in terms of soil erosion rate and runoff potential and identify the most erodible sub catchment.

\section{Materials and Methods}

\subsection{Description of the Study Area}

\subsubsection{Location and Topography}

Katar watershed covers 3326.86 square kilometers $\left(\mathrm{km}^{2}\right)$ is part of the Ziway Shala sub basin of main Ethiopia Rift valley. This internal drainage basin located in the central part of the Main Ethiopian Rift Valley. Geographically it is located between

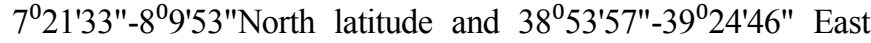
longitude. Katar River and its tributaries drain from southeast highland area to North West and enter Lake Ziway. Topographically, Katar catchment shows a well pronounced variation with the altitude ranging from around $1644 \mathrm{~m}$ above sea level (masl) near Lake Ziway (at the outlet) to about $4171 \mathrm{~m}$ above sea level (m.a.s.l). on the high volcanic ridges along the eastern watershed (Kaka and Galama Mountain).

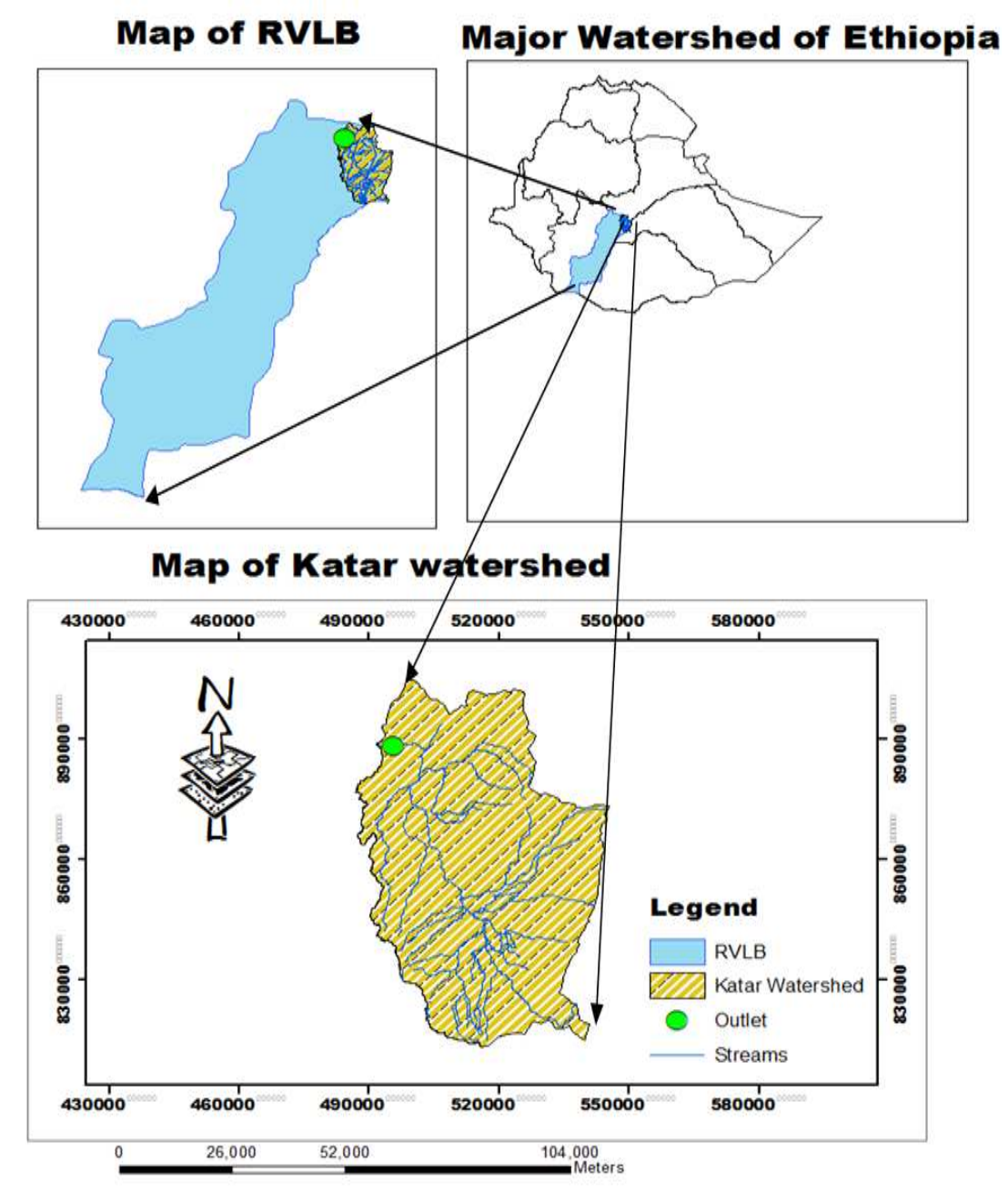

Figure 1. Map of Study Area (source: MOWIE, 2007).

\subsubsection{Climate}

According to the statistical analysis of the climatic data, the climate of the study area can be categorized as semi-arid to sub-humid type with a mean annual rainfall ranging from
$744.8 \mathrm{~mm}$ to $1046.0 \mathrm{~mm}$, and with a mean annual minimum and maximum temperature ranging from $7.3^{\circ} \mathrm{C}$ to $13.8^{\circ} \mathrm{C}$, and from $19.0^{\circ} \mathrm{C}$ to $28.1^{\circ} \mathrm{C}$ respectively. Local monitoring Climatic Variables between 1988-2013 years period for Katar 
watershed are obtained from the National Meteorological Agency (NMA) of Ethiopia.

Table 1. Location of Weather Stations in Katar Watershed, Ethiopia.

\begin{tabular}{llll}
\hline Name & Coordinates & \multicolumn{2}{c}{ Altitude m.a.s.I (m) } \\
\hline & Longitude UTM & Latitude UTM \\
\hline Assela & 508825 & 836762 & 2413 \\
Kulumsa & 508814 & 893143 & 2211 \\
Iteya & 515425 & 894250 & 2060 \\
Sagure & 509931 & 824602 & 2388 \\
Bokoji & 516556 & 809127 & 2480 \\
Ogolcho & 495697 & 888288 & 1682 \\
\hline
\end{tabular}

(Source: NMA)

\subsection{SWAT Input Data Used}

The most important spatial information needed were: Digital Elevation Model (DEM), land use or land cover and a soil.

\subsubsection{Digital Elevation Model}

The DEM is a common data source for developing topography dependent models. It is required to calculate the flow accumulation, stream networks, slope, and watershed delineation. Hence, $30 \mathrm{~m}$ by $30 \mathrm{~m}$ meter grid resolution DEM in raster format was used and projected to Transverse Mercator (UTM) on the spheroid of WGS-84 to correct the errors and fit into the model requirement. It is obtained from Ministry of Water, Irrigation and Electricity (MOWIE) of Ethiopia.

(i). Watershed Delineation

The watershed delineation operation uses and expands ArcGIS version 10.3 and Spatial Analyst extension functions to perform watershed delineation. The first step in the watershed delineation was loading the properly projected DEM. To reduce the processing time of the GIS functions, a mask was created over the DEM around the study area. Next, a polyline stream network dataset was burnt-into force SWAT sub-basin reaches to follow known stream reaches. Burningin a stream network improves hydrological segmentation, and sub-watershed delineation. After the DEM, grid was loaded and the stream networks superimposed, the DEM map grid was processed to remove the non draining zones. The initial stream network and sub-basin outlets were defined based on drainage area threshold approach. The threshold area defines the minimum drainage area required to form the origin of a stream. Besides, those sub-basin outlets created by the interface and the outlet was manually added at the gauging stations where sensitivity analysis, calibration and validation tasks were later performed. Then, watershed delineation activity was finalized by calculating the geomorphic subbasin parameter (Figure 2).

(ii). Hydrologic Response Unit Analysis

Hydrologic response units (HRUs) are lumped land areas within the sub-basin that are comprised of unique land cover, soil, slope and management combinations. In this study, the minimum threshold area required to discreted the sub watershed into homogeneous HRUs were selected as $20 \%$, $20 \%$ and $10 \%$ threshold levels used for the land use, soil and slope respectively in combinations with multiple HRUs were used. The overlaid of land use, soil and slope maps resulted in the definition of 181 HRUs were identified.

During the creation of HRUs, the slope classified into the reasonable range. Accordingly, for this work to minimize complexity and use manageable data and considering the steepness of the area, the slope classified into five classes based on [20]. The results indicated (Table 2) that, more area of watershed covered by a slope ranges from 3-8, 0-3 and 8$15 \%$, which covered an area of 136425.12 ha $(41.01 \%)$, 76226.09 ha $(22.91 \%)$ and 80812.36 ha $(24.29 \%)$ of the total watershed respectively and the least area covered by the slope of $>30 \%$ which account 4541.36 ha $(1.37 \%)$ from the total watershed.
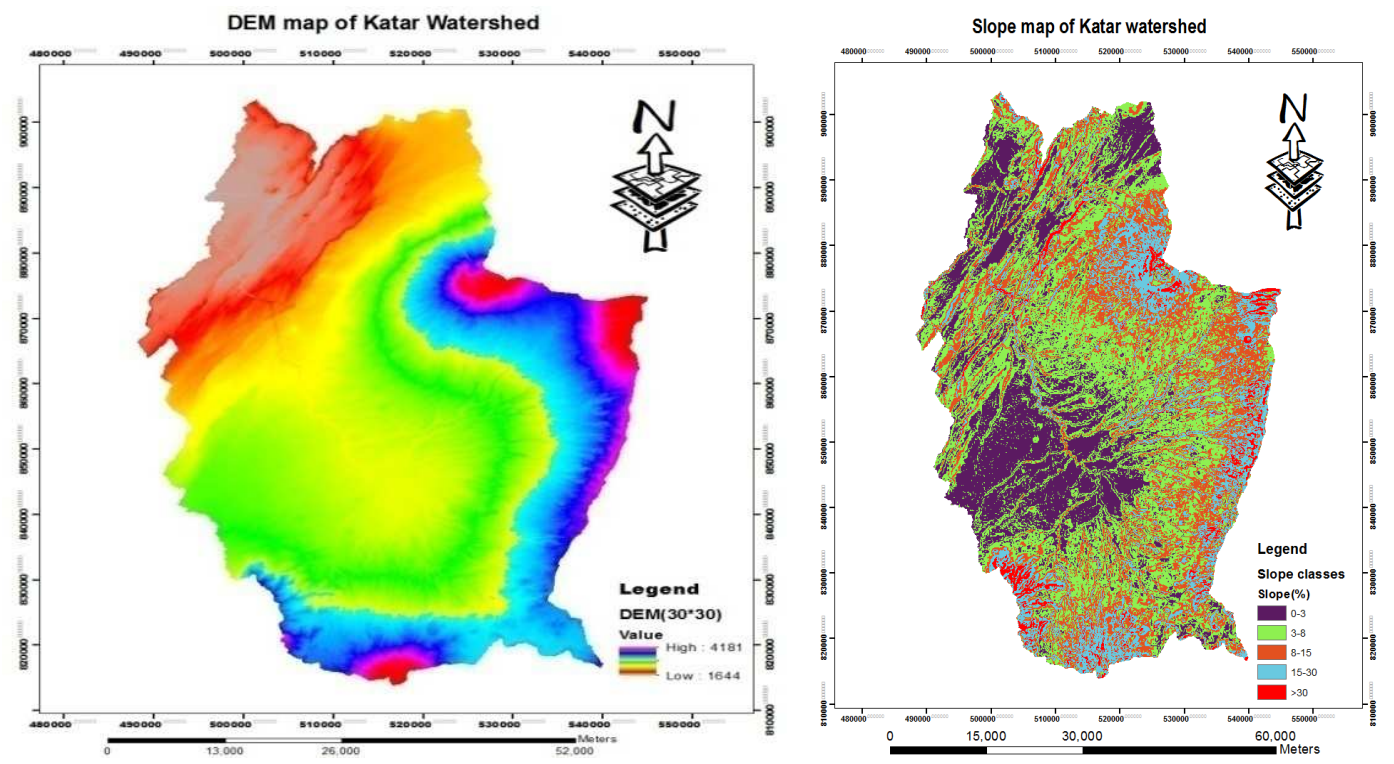

Figure 2. Digital Elevation Model (above) and slope classes (below) (Source: MOWIE, 2007). 
Table 2. Slope classes and the area occupied in ha and percent (\%) of the study area after HRUs definition.

\begin{tabular}{llll}
\hline $\begin{array}{l}\text { Slope range } \\
(\%)\end{array}$ & Kater Watershed & & Area (ha) \\
\cline { 2 - 4 } & Land form & 76226.09 & Area Coverage (\%) \\
\hline $0-3$ & Flat or almost flat & 136425.12 & 41.01 \\
$3-8$ & Gentle slopping, undulating plain & 80812.36 & 24.29 \\
$8-15$ & Rolling plain & 34681.18 & 10.42 \\
$15-30$ & Hilly plain & 4541.36 & 1.37 \\
$>30$ & Steep hilly, very steep slopes, ridges and mountains & 332686.11 & 100 \\
\hline
\end{tabular}

\subsubsection{Land Use/land Cover Data}

The land use land cover data were acquired from the Rift Valley lake Basin Master plan 2007 in the form of shape files. The dominant land use land cover of study area after HRUs definition was as follows; According to the land use land cover data, the major part of the watershed was covered by Intensively Cultivated land which covered about 263287.83 ha (79.14\%) of watershed area, and the lowest part of watershed covered by forest land which account about 291.80 ha $(0.09 \%)$ of watershed from the whole watershed area (Table 3 ).

Table 3. Area coverage by each land use/Land cover type of the study area after the definition of HRUs.

\begin{tabular}{llll}
\hline \multirow{2}{*}{ Major land use } & SWAT & \multicolumn{2}{l}{ Katar Watershed } \\
\cline { 3 - 4 } & Code & Area (ha) & Area (\%) \\
\hline Intensively Cultivated & AGRC & 263287.83 & 79.14 \\
Moderately Cultivated & AGRL & 38590.62 & 11.60 \\
Exposed surface & EXPS & 1399.97 & 0.42 \\
Grassland & PAST & 2395.03 & 0.72 \\
Forest & FRST & 291.80 & 0.09 \\
Afro-Alpine Green Vegetation & FSRE & 9177.65 & 5.76 \\
Shrub-land & RNGB & 7543.21 & 2.27 \\
Total & & 332686.11 & 100 \\
\hline
\end{tabular}

\subsubsection{Soil Data}

Soil data were obtained from Rift Valley Lakes Basin (RVLB) integrated resource development master plan study project [21]. Some SWAT soil parameters were calculated by using Pedo Transfer Function (PTF) developed by [29]. From the identified soil, Halpic Luvisols (LVh) is the dominant soil type covered an area of 194399.93 ha $(58.43 \%)$ and Eutric Vertisols (VRe) soil type covered lowest area (13597.25 ha) $(4.09 \%)$ of watershed from the total area of the study watershed (Table 4).

Table 4. Major soil types and area coverage (ha, \%) of the study area after HRUs definition.

\begin{tabular}{llll}
\hline & & \multicolumn{2}{l}{ Katar Watershed } \\
\hline Major Soil Types & Depth(cm) & Area (ha) & Area (\%) \\
\hline Vitric Andosols(ANz) & 2000 & 20111.75 & 6.05 \\
Rhodic Nitisols(NTr) & 1200 & 104577.18 & 31.43 \\
HalpicLuvisols(LVh) & 2000 & 194399.93 & 58.43 \\
EutricVertisols(VRe) & 1450 & 13597.25 & 4.09 \\
Total & & 332686.11 & 100 \\
\hline
\end{tabular}

\subsection{Meteorological Data}

Daily meteorological data obtained from National Meteorological Agency (NMA) of Ethiopia for the stations of: Asela, Eteya, Ogolcho, Kulumsa, Bokoji and Sagure from 1988 to 2013 . However, some of the missing data were filled using predictions with linear regression equations. After filled missed rainfall data, Double Mass-Curve (DMC) analysis was used to check whether the existence was inconsistency or not in rain gauge stations. Finally, the weather data were prepared in text file format as required by the SWAT model.

\subsection{Discharge or Runoff Data}

The daily observed stream flow data was obtained at the outlet (Habura) of the watershed for 26 (1988-2013) years from Hydrology Department of Ministry of Water, Irrigation and Electricity for Katar River feeding to Lake Ziway. However, some of the missing daily discharge datas were filled using linear regression equation between the downstream and the upstream gauge for Katar river discharge relation. Then, after missed data were filled, the stream flow data used for calibrating and validating the model.

\subsection{Sensitivity Analysis}

The sensitivity analysis for this study area was done using Global sensitivity analysis methods. Model Sensitivity analysis is the step where the uncertainties of the modeling process could be evaluated and prioritized for the inclusion into the calibration process. It can be categorized into four classes.

Table 5. Sensitivity analysis index (Source: [28]).

\begin{tabular}{lll}
\hline Class & Index (I) & Sensitivity \\
\hline I & $|\mathrm{I}| \geq 1.00$ & Very high \\
II & $0.2 \leq|\mathrm{I}|<1.00$ & High \\
III & $0.05 \leq|\mathrm{I}| \mid<0.2$ & Medium \\
IV & $0 \leq|\mathrm{I}|<0.05$ & Small to neglible \\
\hline
\end{tabular}

\subsection{Model Performance Evaluation}

The performance of the model was evaluated by assessing the correlation between simulated and observed values. SWAT-CUP 2012 version was used to calibrate the model using Sequential uncertainty fitting (SUFIver2) [2]. In this study, during both calibration and validation periods, the goodness of-fit between the simulated and measured runoff was evaluated using the coefficient of determination $\left(R^{2}\right)$, Percent difference or percent bias (PBIAS) and the NashSutcliffe coefficient of efficiency [23]. According to SWAT developers [28]; they assumed an acceptable calibration for hydrology at a PBIAS $< \pm 25 \%, \mathrm{R}^{2}>0.6$ and ENS $>0.5$. To decide the accuracy of the model the value of each index obtained by the model compared with the value of hydrologic model performance ratings. 
Table 6. General performance evaluation for stream flow on monthly time steps.

\begin{tabular}{llll}
\hline \multicolumn{4}{c}{ Objective functions } \\
\hline $\mathbf{R}^{\mathbf{2}}$ & ENS & PBIAS & Performance Rating \\
\hline $0.7<\mathrm{R}^{2}<1.00$ & $0.75<\mathrm{ENS} \leq 1.00$ & PBIAS $< \pm 10 \%$ & Very Good \\
$0.6<\mathrm{R}^{2}<0.7$ & $0.65<\mathrm{ENS} \leq 0.75$ & $\pm 10 \%<$ PBIAS $< \pm 15 \%$ & Good \\
$0.50<\mathrm{R}^{2}<0.6$ & $0.50<\mathrm{ENS} \leq 0.65$ & $\pm 15 \%<$ PBIAS $< \pm 25 \%$ & Satisfactory \\
$\mathrm{R}^{2}<0.50$ & ENS $\leq 0.50$ & PBIAS $\geq \pm 25 \%$ & Unsatisfactory \\
\hline
\end{tabular}

(Source: [22, 23])

The $\mathrm{R}^{2}$ is the magnitude of the linear relationship between the observed and the simulated values, and calculated as:-

$$
\mathrm{R}^{2}=\left\{\frac{\sum_{\mathrm{i}=1}^{\mathrm{n}}\left(\mathrm{O}_{\mathrm{i}}-\overline{\mathrm{O}}\right)\left(\mathrm{S}_{\mathrm{i}}-\overline{\mathrm{S}}\right)}{\sqrt{\sum_{\mathrm{i}=1}^{\mathrm{n}}\left(\mathrm{O}_{\mathrm{i}}-\overline{\mathrm{O}}\right)^{2}} \sqrt{\sum_{\mathrm{i}=1}^{\mathrm{n}}\left(\mathrm{S}_{\mathrm{i}}-\overline{\mathrm{S}}\right)^{2}}}\right\}^{2}
$$

Where: Oi is the observed flow, $\mathrm{Si}$ is the modeled flow, and $\overline{\mathrm{O}}$ is the mean of the observed flow and $S$ is of the simulated flows.

$$
\text { ENS }=1-\left[\frac{\sum_{\mathrm{i}=1}^{\mathrm{n}}\left(\mathrm{Q}_{\mathrm{m}}-\mathrm{Q}_{\mathrm{s}}\right)^{2}}{\sum_{\mathrm{i}=1}^{\mathrm{n}}\left(\mathrm{Q}_{\mathrm{m}}-\mathrm{Q}_{\mathrm{s}}\right)^{2}}\right]
$$

Where: $\mathrm{Q}_{\mathrm{m}}$ is the observed flow, $\mathrm{Q}_{\mathrm{s}}$ is the simulated flow of the simulation.

The percent difference or percent bias (PBIAS) describes the tendency of the simulated data to be greater or smaller than the observed data values over a specified period (usually the entire calibration or validation period). A value close to $0 \%$ is best, with lower values indicating satisfactory model simulation

$$
\mathrm{PBIAS}=\frac{\sum_{\mathrm{i}=1}^{\mathrm{n}}(\mathrm{Qm}-\mathrm{Qs}) * 100}{\mathrm{Qm}}
$$

Where $\mathrm{Q}_{\mathrm{m}}$ is the observed flow, $\mathrm{Q}_{\mathrm{s}}$ is the simulated flow of the simulation and isaverage stream flow.

\section{Results and Discussions}

\subsection{Sensitive Parameters for Stream Flow}

According to the result, from the fifteen hydrologic parameters twelve hydrologic parameters were highly sensitivity and selected based on [18] to compute the sensitivity of the streams' flow and ranked based on the t-Stat (Table 7). The twelve highly sensitive parameters were the most driven parameters of stream flow and the left were none sensitive to stream flow. Therefore, attention was given to most twelve highly sensitive parameters during model calibration.

Table 7. Parameters used for sensitivity analysis.

\begin{tabular}{lll}
\hline SWAT Parameters & Descriptions & Rank \\
\hline Sol_K & Saturated Hydraulic conductivity & -100.00 \\
GWQMN & Threshold water depth in shallow aquifer (mm) & 50.00 \\
HRU_SLP & Average slope steepness & 2 \\
CN2 & SCS runoff curve number & 3 \\
GW_DELAY & Groundwater delay(days) & -30.00 \\
SOL_AWC & Depth from soil surface to bottom & -28.00 \\
ESCO & Soil evaporation compensation factor & 20.00 \\
ALPHA_BF & Base flow alpha factor(days) & 12.00 \\
EPCO & Plant uptake compensation factor & -3.50 \\
SOL_BD & Moist bulk density & -3.50 \\
CANMX & Maximum Canopy storage & 2.50 \\
CH_K2 & effective hydraulic conductivity in the main channel & 7 \\
OV_N & Manning's "n" value for overland flow & 8 \\
SURLAG & Surface lag time & 9 \\
GW_REVAP & Groundwater "revap" coefficient & 1.50 \\
\hline
\end{tabular}

\subsection{Model Performance Evaluation}

\subsubsection{Stream Flow Calibration}

Calibration of stream flow has been performed depending on observed flow measurements. Final adjusted calibrated

\begin{tabular}{|c|c|c|c|c|}
\hline SWAT Parameters & Descriptions & Range & Initial Value & Final Calibrated Value \\
\hline $\mathrm{CN} 2$ & SCS runoff curve number & & $*$ & 0.0012 \\
\hline CANMX & Maximum Canopy storage & $0-10$ & 0 & 8.62 \\
\hline HRU_SLP & Average slope steepness & $0-1$ & 0 & 0.05 \\
\hline OV_ $\bar{N}$ & Manning's " $n$ " value for overland flow & $0.01-30$ & 0.03 & 5.02 \\
\hline
\end{tabular}
parameters and fitted values for stream flow as shown below (Table 8).

Table 8. Final calibrated parameters and fitted values of flow. 


\begin{tabular}{lllll}
\hline SWAT Parameters & Descriptions & Range & Initial Value & Final Calibrated Value \\
\hline SOL_BD & Moist bulk density & $0.85-2.5$ & 0.85 & 2.5 \\
Sol_K & Saturated Hydraulic conductivity & $0-2000$ & 0 & 5.52 \\
SOL_AWC & Depth from soil surface to bottom & $0-1$ & 0 & 0.175 \\
CH_K2 & effective hydraulic conductivity in the main channel & $0.01-500$ & 0.01 & 23.44 \\
EPCO & Plant uptake compensation factor & $0-1$ & 0 & 1 \\
GW_REVAP & Groundwater "revap" coefficient & $0.02-0.2$ & 0.02 & 0.062 \\
SURLAG & Surface lag time & $0.05-24$ & 0.05 & 9.99 \\
ALPHA_BF & Base flow alpha factor(days) & $0-1$ & 0 & 0.00 \\
GW_DELAY & Groundwater delay(days) & $0-500$ & 0 & 41.5 \\
ESCO & Soil evaporation compensation factor & $0-1$ & 0 & 0.49 \\
GWQMN & Threshold water depth in shallow aquifer $(\mathrm{mm})$ & $0-5000$ & 0 & 533 \\
\hline
\end{tabular}

* SWAT default parameters.

After adjusting the highly sensitive parameters manually, calibration was then performed by using SUF-2 set up during the periods of 1990-2005 (1988 and 1989 used as a "warm-up" year). Calibration resulted of the correction coefficient $\left(\mathrm{R}^{2}\right)$, NashSuttcliffe simulation efficiency (NSE) and percent difference or percent bias (PBIAS) were $0.8,0.6$ and 0 respectively (Table 9), and shown a good agreement between measured and simulated monthly stream flow according to $[22,23]$. The results fulfilled the requirements suggested by [28] for PBIAS $< \pm 25 \%, \mathrm{R}^{2}>0.6$ and ENS $>0.5$. In general, the model performs well in predicting the runoff from Katar watershed. A best-fit trend line was applied to each scatter plot, and the resulting line equation used to quantify model performance.

Table 9. Calibration results of average monthly observed and simulated flow.

\begin{tabular}{ll}
\hline Parameter & Calibrated (1990-2005) \\
\hline $\mathrm{R}^{2}$ (coefficient of determination) & 0.8 \\
NSE(Nash-Sutcliffe model efficiencies) & 0.6 \\
PBIAS (percent Bias) & 0 \\
\hline
\end{tabular}

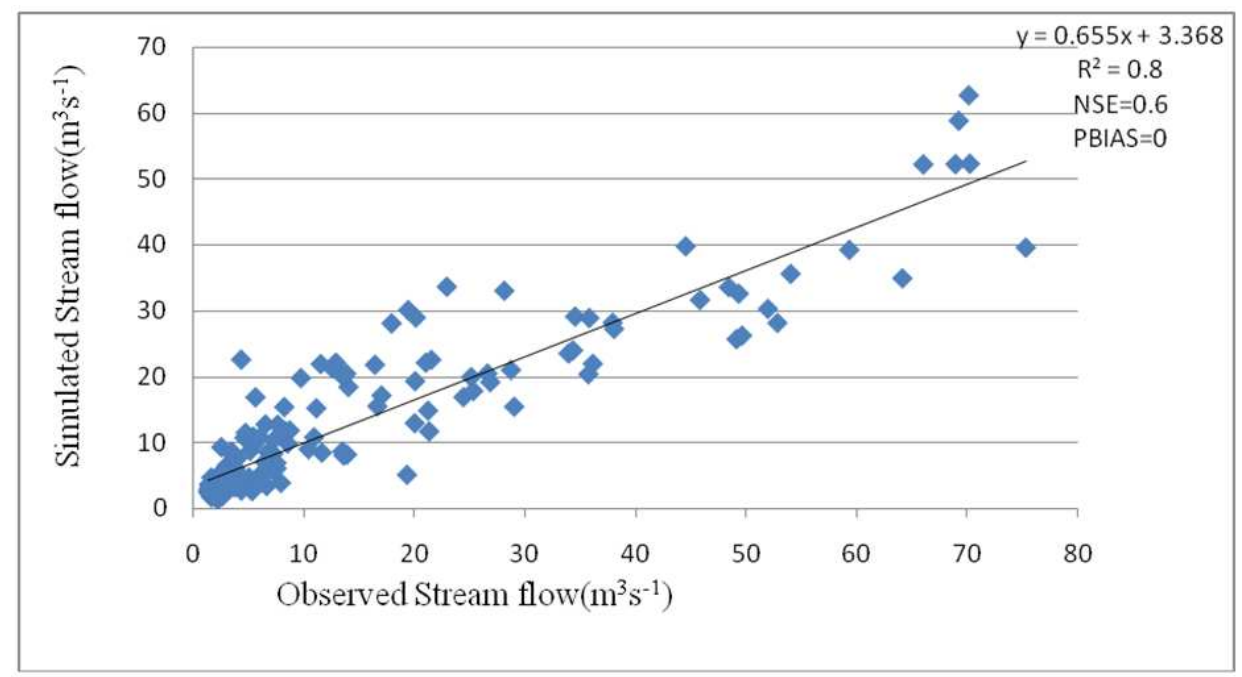

Figure 3. Comparison between observed and simulated stream flow for calibration period (1990-2005) at Habura gauging station.

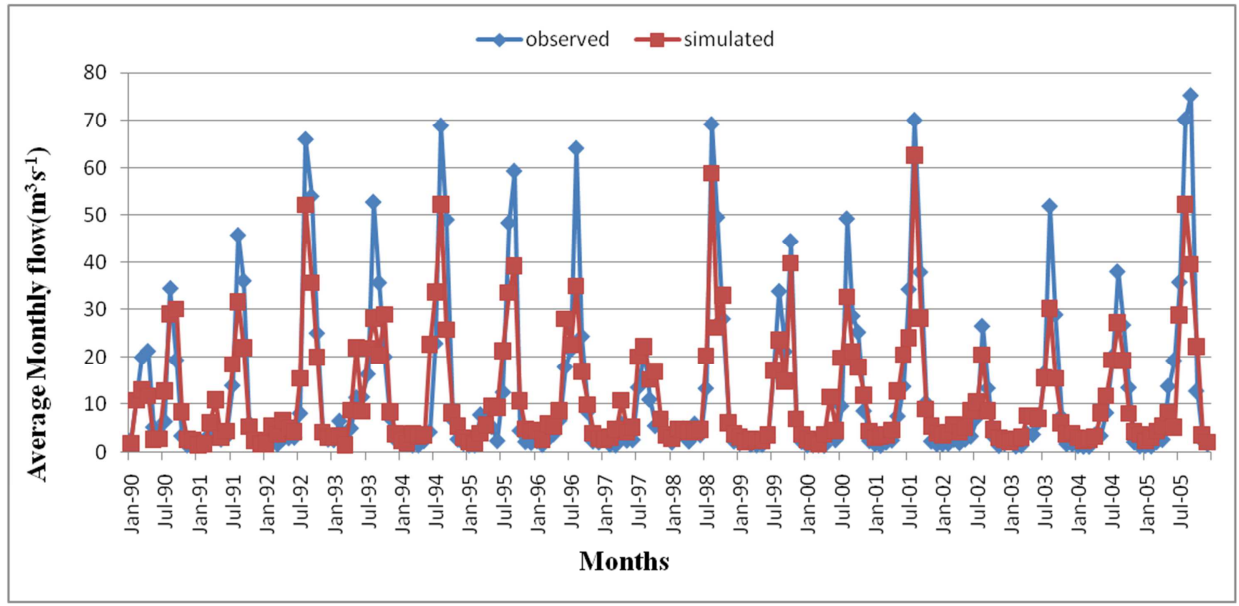

Figure 4. Simulated and observed monthly stream flow during calibration period (1990-2005) at Habura gauging station. 


\subsubsection{Stream Flow Validation}

Stream flow validation was conducted to ensure the validity of the calibration process from January 1st, 2006 to December 31, 2013. The $\mathrm{R}^{2}$, Nash-Suttcliffe simulation efficiency (NSE) and PBIAS were obtained 0.67, 0.55 and 1.2 respectively (Figure 5 and Table 10), which showed a good correlation with the gauged stream flow. The results fulfilled the requirements suggested by [28] for PBIAS $<$ $\pm 25 \%, \mathrm{R}^{2}>0.6$ and ENS $>0.5$. In general, the model performs well in predicting the runoff from Katar watershed. A best-fit trend line was applied to each scatter plot, and the resulting line equation was used to quantify model performance.

Table 10. Validation results of average monthly observed and simulated flow.

\begin{tabular}{ll}
\hline Parameter & Calibrated (2006-2013) \\
\hline $\mathrm{R}^{2}$ (coefficient of determination) & 0.67 \\
NSE(Nash-Sutcliffe model efficiencies) & 0.55 \\
PBIAS (percent Bias) & 1.2 \\
\hline
\end{tabular}

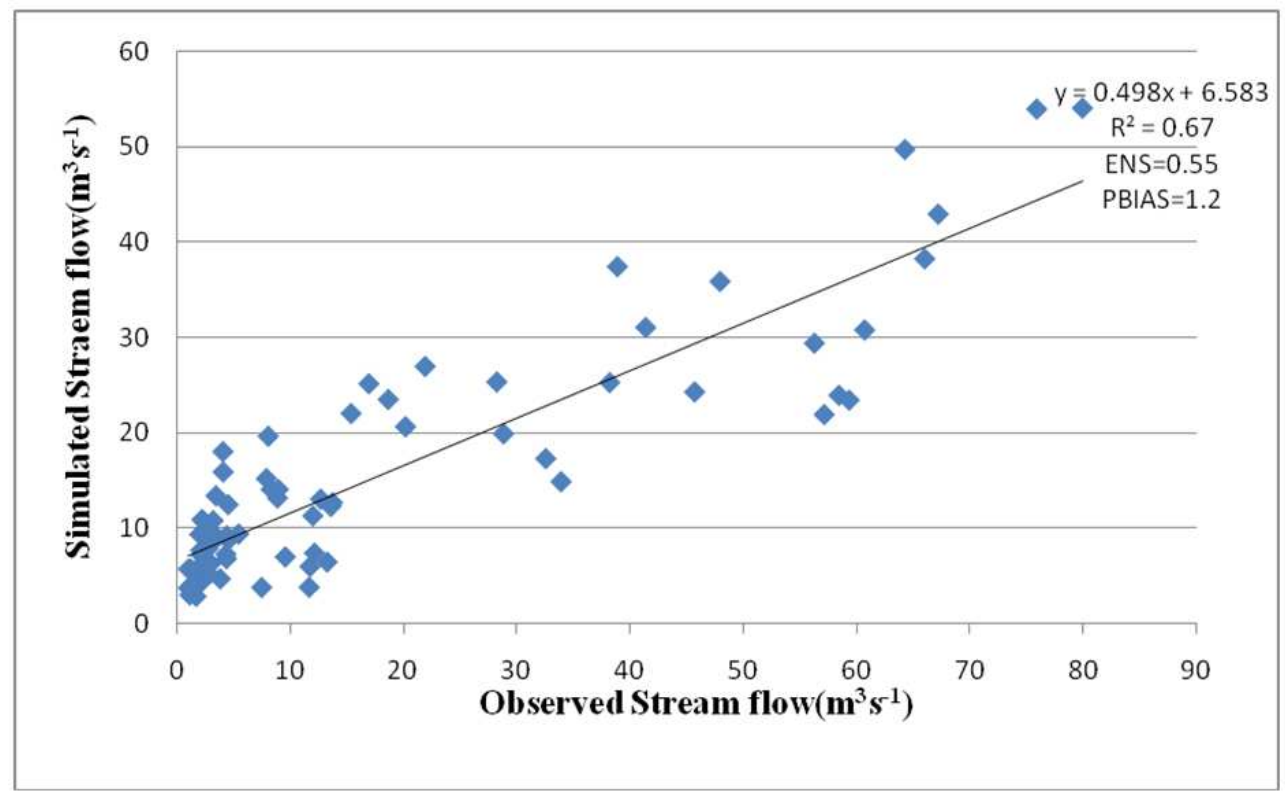

Figure 5. Comparison between observed and simulated stream flow for validation period (2006-2013) at Habura gauging station.

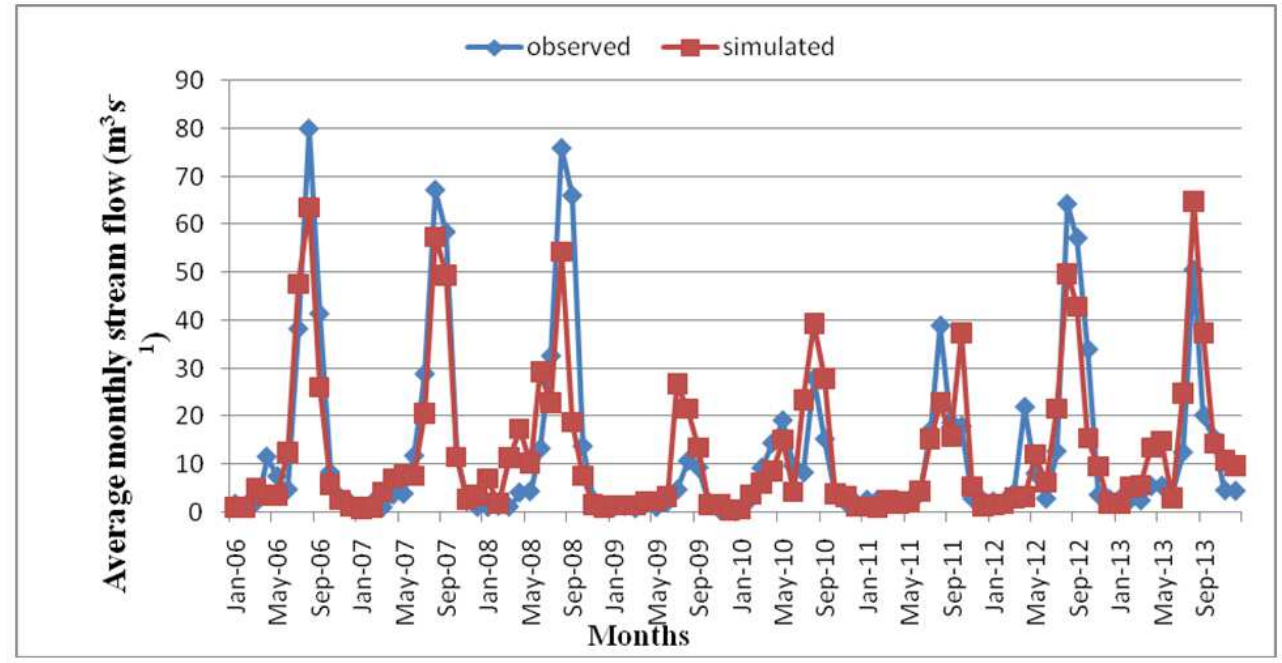

Figure 6. Simulated and observed monthly stream flow during Validation period (2006-2013) at Habura gauging station.

\subsection{Spatial Distribution of Sediment Yield and Runoff in Katar Watershed}

Assessing the soil formation rates of an area is vital for the evaluation of soil loss rate and the potential of soil regeneration once soil erosion is substantially reduced. The degree of erosion hazard in the Katar sub-watershed were reclassified in to four (Table 11) different erosion hazard classes based on Getachew et. al, (2017). According to prioritization map, sediment loss categorized into four (4) classes, such that $0-11,11-18,18-30$ and $30-37.6$ tha $^{-1} \mathrm{yr}^{-1}$. 
Table 11. Sediment yield losses and Severity classes of Katar Watershed.

\begin{tabular}{|c|c|c|c|c|c|}
\hline Annual soil loss $\left(\right.$ tha $\left.^{-1} \mathrm{yr}^{1}\right)$ & Sub watershed & Severity classes & Area(ha) & Area (\%) & Severity Ranks \\
\hline $0-11$ & $1,2,3,5,7,8,9,10,11,14,16,17,18,19,23,26,27,28,29,30,33,34,35$ & Low & 207450.02 & 62.360 & 4 \\
\hline $11-18$ & $4,13,21$ & Moderate & 13117.30 & 3.940 & 3 \\
\hline $18-30$ & $6,12,15,22,25,31$ & High & 80862.16 & 24.304 & 2 \\
\hline $30-37.6$ & $20,24,32$ & Very high & 31255.70 & 9.396 & 1 \\
\hline
\end{tabular}

According to this study, sub watershed $6,12,15,20,22$, $24,25,31$ and 32 were categorized under high and very high soil loss and covered $33.7 \%$ of watershed in the study area (Figure 7 and Table 11). The soil losses from these sub watershed is greater than maximum tolerable soil loss rate $\left(>18\right.$ tha $\left.^{-1} \mathrm{yr}^{-1}\right)$ and high surface runoff generated from these sub watershed and identified as erosion prone area in Katar watershed (Figure 7 and Table 11). The main reason for generating more runoff and sediment yield could be land degradation, poor land cover, improper land management (lack of soil and water conservation) and cultivating undulating slope without conservation. The acceptable soil loss that can maintain the economy and a high level of production $[33,9,12]$ ranges from 5 to 11 tha $^{-1} \mathrm{yr}^{-1}[27,10]$. However, the soil loss from these sub watershed; is above this range and the area is more vulnerable to soil loss. Erosion is more aggravated on wide range of agricultural uses, and susceptible to structure deterioration with tillage. These factors were responsible for aggravating the soil loss and facilitated the surface runoff to wear out the top soil in a higher rate from watershed.

Among 35-sub watershed, 3-sub watershed (4, 13 and 21) were fallen under moderate soil losses, which were given moderate priority class and the annual soil loss from this watershed ranges from 11 to 18 tha $^{-1} \mathrm{yr}^{-1}$ (Table 11). This study agreed with the study of [16], who stated that range of the tolerable soil loss level for the various agro-ecological zones of Ethiopia was found from 2 to $18 \mathrm{tha}^{-1} \mathrm{yr}^{-1}$. However, the result from the three sub watershed above acceptable soil loss that can maintain the economy and a high level of production $[33,9,12]$ ranges from 5 to $11 \mathrm{tha}^{-1} \mathrm{yr}^{-1}[27,10]$ and also above the range of soil formation rate in the study area ranges from 6-10 tha ${ }^{-1} \mathrm{yr}^{-1}$ [15]. These sub watersheds were dominated by moderately gentle slope, agriculture and clay loam dominant soil (moderate infiltration capacity). Hence soil type, topography and agricultural activity is the principal factor for the sediment loss and surface runoff.

The rest $23 \mathrm{sub}$ watersheds were fallen under low soil loss rate $<11$ tha $^{-1} \mathrm{yr}^{-1}$ (Table 11 and Figure 7). The area classified under low soil loss is $62.36 \%$; which is covered large area of watershed (Table 11). The result was agreed with the result of $[9$, 12], who state that the acceptable soil loss that can maintain the economy and a high level of production ranges from 5 to 11 tha ${ }^{1} \mathrm{yr}^{-1}[27,10]$. In addition, soil formation rate in the study area ranges from 6-10 tha $\mathrm{yr}^{-1}$ [15]. Thus, this study agreed with above two authors; because the result of the study was within acceptable range $\left(0-11\right.$ tha $\left.^{-1} \mathrm{yr}^{-1}\right)$. However, higher/steep slopes are found along the boundaries of the watersheds and had less impact on the soil loss because of land cover and Afro Alpine Green Vegetation and forest covers this area. A report from China [19] indicated that, land with lower vegetation cover implying the extent of soil erosion and high amount of surface runoff generated. Similarly, a Nigerian study by [26] reported greater soil erosion in lands with poor vegetation cover. Hence, land cover took a lion share in reducing soil erosion and runoff potential by increasing infiltration capacity.
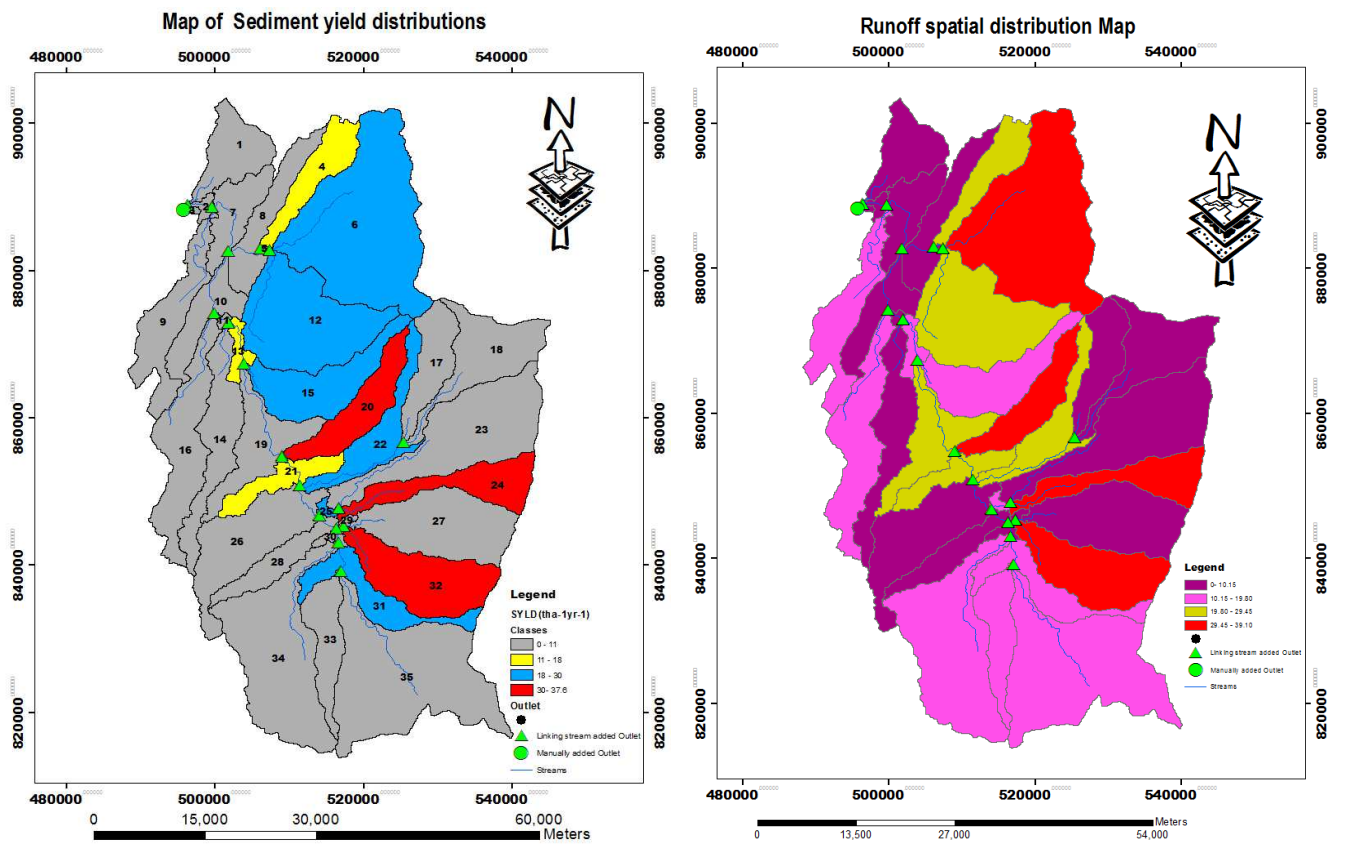

Figure 7. Map of sediment loss (above) and Runoff (below) of Katar watershed. 


\subsection{Prioritization for Intervention Planning}

Because of resource limitations, implementing of soil conservation measures or watershed management in the entire watershed at a time is impractical. Thus, prioritization of intervention areas based on the severity and risks of soil erosion is imperative. The Katar watershed was classified and ranked into four priority classes indicated in Table 11 and Figure 7. Hence, based on the results, sub watershed 6, 12, $15,20,22,24,25,31$ and 32 were hotspot erosion area and prioritized for intervention (Table 11). The total area that soil erosion rate above the maximum tolerable erosion limit of 18

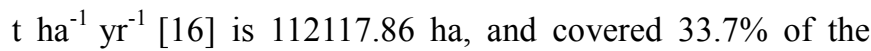
entire watershed (Table 11). Reasonable assessment of soil erosion is the core of any decision making.

In addition, similar studies stated that, undertaking soil conservation measures based on the given priority is a better option as also suggested by $[5,1,3,14]$ for their respective study sites. Therefore, priorities for intervention should be focused on high and very high soil eroded sub watershed to keep natural balance and minimized the effects siltation at downstream of the study area.

In generally, agricultural practice without conservation measure will aggravate the runoff processes in the study area. On flat slopes, deposition of sediments is the major constraint that can affect the down watershed mainly Lake Ziway and hydrology of watershed, and this constrains can be improved by applying integrated watershed management.

\section{Conclusions and Recommendations}

The SWAT-CUP SUF 2 model performance criteria for flow simulation resulted $\overline{\mathrm{R}}^{2}=0.8$, NSE $=0.6$, and PBIAS $=0$ for calibration and $\left(\mathrm{R}^{2}=0.67\right.$, NSE $=0.55$ and $\left.\mathrm{PBIAS}=1.2\right)$ for validation periods, respectively. The results showed a good agreement between the measured and simulated average monthly stream flows during the calibration and validation periods. The SWAT model performed well in predicting the stream flow from the study watershed and the results were acceptable.

Generally, sub watershed $6,12,15,20,22,24,25,31$ and 32 were identified and more susceptible to soil erosion and more attention has to be given to this area, and the required treatments should be used on these area; such as practicing strip planting, terracing, soil bund, contour farming and others to reduce runoff volume and soil erosion. These structures should be practices in all land use of Katar watershed in generally, particularly on agricultural land use (intensively cultivated land). Identifying and prioritizing erosion susceptible areas for intervention are quite essential for this study area. On slope greater than $30 \%$ no need of conducting any agricultural activities, rather the area should be protected and conducting rehabilitation. The result of the study could help different stakeholders to plan and implement appropriate watershed management strategies in the study area. Therefore, future study will be focused on further analysis of the impacts of climate and land use change as well assoil and water conservation on the stream flow and sediment yield in the study watershed. In conclusion, the model developed could be used in prediction model to take appropriate measures in advance.

\section{Conflict of Interest Statement}

The authors declare that they have no competing interests.

\section{Acknowledgements}

The authors would like to thanks Ethiopian Road Authority (ERA) for financing the project. In addition, my thanks goes to National Meteorological Agency (NMA), Ministry of Water, Irrigation and Electricity (MoWIE) and Rift Valley Lake Basin Authority (RVLBA) for providing all necessary materials and supports.

\section{References}

[1] Abate, 2011. Estimating soil loss rates for soil conservation planning in the Borena woreda of South Wollo highlands, Ethiopia. J Sustain Dev Afr 13 (3): 87-106.

[2] Abbaspour, K. C. (2007). Modelling hydrology and water quality in the pre-alpine/alpine Thur watershed using SWAT. J. Hydrol. 333, 413-430.

[3] Amare, S, Nega, C, Zenebe, G, Goitom, T, Alemayoh, T. 2014. Landscape-scalesoil erosion modeling and risk mapping of mountainous areas in easternescarpment of Wondo Genet watershed, Ethiopia. Int Res J AgricSci SoilSci 4 (6):107-116.

[4] Bekele S, Holden, ST. 1998. Resource degradation and adoption of land conservation technologies in the Ethiopian Highlands: a case study in Andit Tid, North Shewa, Ethiopia. Agric Econ 18:233-247.

[5] Bewket, Teferi,. 2009 Assessment of soil erosion hazard and prioritization for treatment at the watershed level: case study in the Chemoga watershed, Blue Nile basin, Ethiopia. Land Degrad Dev 20:609-622.

[6] Bobe, B. 2004. Evaluation of Soil Erosion in the Harerge region of Ethiopia using soil loss models, rainfall simulation and traits. Doctoral Thesis. University of Pretoria. 5pp.

[7] Dadi, D., Hossein, A., Feyera, S., Ketema, A., Fatemeh, T., Till, S. 2016. Urban sprawl and its impacts on land use change in Central Ethiopia. J. Urban For. Urban Green. 16, 132-141.

[8] Desta, L, Carucci, V, Wendem-Ageňehu, A, Yitayew, A. 2005. Community based participatory watershed development: A guideline. Ministry of Agriculture and Rural Development, Addis Ababa, p 62.

[9] FAO. 1986. Ethiopian highlands reclamation study, Ethiopia. Final Report. Rome, FAO.

[10] Foster, G. R., Yoder, D. C., Weesies, G. A., McCool, D. K., McGregor, K. C. and Bingner, R. L. 2002. User's GuideRevised Universal Soil LossEquation Version2 (RUSLE2). USDA - Agricultural Research Service, Washington, DC. 
[11] Gashaw, T. Tulu, T.; Argaw, M. 2017. Erosion risk assessment for prioritization of conservation measures in Geleda watershed, Blue Nile basin, Ethiopia. Environ. Syst. Res., 6, $1-14$.

[12] Gebreyesus, B, Kirubel, M. 2009. Estimating soil loss using Universal Soil Loss Equation (USLE) for soil conservation planning at Medego Watershed, Northern Ethiopia. J Am Sci 5 (1): 58-69.

[13] Gete, Z. 2006. Integrated management of watershed experiences in Eastern and Central Africa: Lessons from Ethiopia. In: Shiferaw B and Rao KPC (eds): Integrated management of watersheds for agricultural diversification and sustainable livelihoods in Eastern and Central Africa: lessons and experiences from semi arid South Asia. Proceedings of the international workshop held at ICRIS at Nairobi, 6-7 December 2004, p 120.

[14] Gizachew, A. 2015. A geographic information system based soil loss andsediment estimation in Zingin watershed for conservation planning, Highlands of Ethiopia. World Appl Sci J 33 (1): 6979.

[15] Hurni, H. 1983. "Soil Formation Rates in Ethiopia" Ethiopian High lands Reclamation Study, Hydrologic modeling. USDA ARS-S-9. 76 pp.

[16] Hurni, H. 1985. Erosion-productivity-conservation systems in Ethiopia. In: Sentis IP (ed) Soil conservation and productivity, Proceedings 4thinternational conference on soil conservation, Maracay, Venezuela p 654-674.

[17] Jansen, H., Hengsdijk, H., Legesse, D., Ayenew, T., Hellegers, P., Spliethoff, P. 2007. Land and water resources assessment in the Ethiopian Central Rift Valley; project: ecosystems for water, food and economic development Project in the Ethiopian Central Rift Valley. Alterra report No. 1587, ISSN 15667197, Wageningen, The Netherlands.

[18] Lenhart, T., K. Eckhardt, N. Fohrer and H. G. Frede. 2002. Comparison of two different approaches of sensitivity analysis. Physics and Chemistry of the Earth, 27: 645-654.

[19] Luo, Z, Deng, L, Yan, C. 2014. Soil erosion under different plant cover types and its influencing factors in Napahai Catchment, Shangri-La County, Yunnan Province, China, International. J Sustain Dev World Ecol. doi: 10.1080/13504509.2014.924448.

[20] Ministry of Agriculture and Rural Development (MoARD). 2005. Ethiopia's Agricultural Sector Policy and Investment Framework (PIF) 2010-2020. Draft Final Report, p 39.

[21] MOWIE, 2007. Rift Valley Lake Basin Integrated Resources Development Master Plan Study project.

[22] Moriasi, D. N,. 2007. Model evaluation guidelines for systematic quantification of accuracy in watershed simulations. Transactions of the ASABE 50 (3): 850-900.

[23] Nash, J. E.; Sutcliffe, J. 1970. River flow forecasting through conceptual models: Part I. A discussion of principle. J. Hydrol. $10,282-290$.
[24] Menale K, Mahmud Y, Kohlin, G. 2009. The role of production risk in sustainableland-management technology adoption in the Ethiopian Highlands. Working papers in economics, No 407. Gothenburg: University of Gothenburg, $p$ 25 .

[25] Nigussie H, Ademnur B, Atsushi T, Mitsuru T, Derege, T. 2012. Integrated watershed management as an effective approach to curb land degradation:a case study of the Enabered watershed in northern Ethiopia. Environ Manage 50: $1219-1233$.

[26] Oruk EO, Eric NJ, Ogogo,. AU. 2012. Influence of soil textural properties and land use cover type on soil erosion of a characteristic ultisols in Betem, Cross River Sate, Nigeria. J Sustain Dev 5 (7): 104-110.

[27] Renard KG, Foster GR, Weesies GA, McCool DK, Yoder DC. 1996. Predictingsoil erosion by water: a guide to conservation planning with the Revised Universal Soil Loss Equation (RUSLE). United States Department of Agriculture, Handbook No. 703, p 384.

[28] Santhi, C., J. G. Arnold, J. R., Williams, W. A. Dugas, R. Srinivasan and L. M. Hauck, 2001. Validation of the SWAT model on a large river basin with point and nonpoint sources: Journal of The American Water Resources Association 37 (5): 1169-1188.

[29] Saxton K. E., Rawls W. J. 2006. Soil Water Characteristic Estimates by Texture and Organic Matter for Hydrologic Solutions. Soil Science Society of Agronomy Journal 70 (5): 1569-1578.

[30] Shimelis, B. D.; Melesse, A. M. 2015. Climate Change Impact on Sediment Yield in the Upper Gilgel Abay Catchment, BlueNile Basin, Ethiopia. In Landscape Dynamics, Soils and Hydrological Processes in Varied Climates; Springer International Publishing: Cham, Switzerland, Volume 7, pp. 615-644.

[31] SCRP, 1985. Soil Conservation Research Project Database Report 1982-1993. Ministry of Agriculture and University of Berne, Series Report III. Hundelafto Research Unit, Institute of Geography, University of Berne, Switzerland.

[32] Tibebe, D., Bewket, W. 2011. Surface runoff and soil erosion estimation using the SWAT model inthe Keleta catchment, Ethiopia. Land Degradation and Development, v. 22, n. 6, p. 551-564.

[33] Wischmeier, W. H., and Smith, D. D. 1978. Predicting rainfall erosion losses: A guide to conservation planning. U.S. Department of Agriculture Handbook No. 537, Washington, D.C., U.S. Government Printing Office.

[34] Zeray, L., Roehrig, J., Alamirew, D., 2006. Climate change impacton Lake Ziway watershed water availability, Ethiopia. In: Paper Presented at the Conference on International Agricultural Research for Development. University of Bonn. 